\title{
SPOTLIGHT
}

\section{Serbian Historiography after 1991}

\author{
Christian Axboe Nielsen
}

Aarhus University, Department of Culture and Society, Jens Chr. Skous Vej 5, 8000 Aarhus C, Denmark christian.a.nielsen@cas.au.dk

Few countries in Europe have witnessed as much turbulence during the past quarter century as the seven states which emerged from socialist Yugoslavia after it dissolved amidst a catastrophic series of wars of succession. Although actual armed conflict only took place in Serbia (then still including Kosovo in the rump state Federal Republic of Yugoslavia) in 1998 and 1999, Serbia directly participated in the wars of Yugoslav succession beginning in 1991 in Slovenia, Croatia and Bosnia and Herzegovina, and then finally in Kosovo. For nearly a decade from 1992 until 2001 Serbia's economy languished under the combination of a kleptocratic regime, expensive and protracted military engagements and international sanctions. The long Serbian transition entered a new phase in October 2000, when Yugoslav President Slobodan Milošević was ousted by a very heterogeneous political coalition whose leaders shared only an intense antipathy for Milošević. The Federal Republic of Yugoslavia was transformed into the short-lived state union of Serbia and Montenegro, which disappeared when Montenegro declared its independence in 2006, followed by Kosovo in 2008.

Penning such a brief summary of the evolution of Serbia since 1991 elides most of the details and much of the complexity of recent Serbian history. Yet in the shortest possible way it serves to underline that Serbia as a country has undergone a protracted and painful post-Yugoslav transition, which has left indelible marks. All of this turbulence could not but impact both the historians and historiography of Serbia. ${ }^{1}$ Moreover, a number of historians participated directly as advisors to key actors in the events of the 1990s, and they were complicit in the weaponisation of history, in particular that of the mass atrocities of the Second World War. ${ }^{2}$ Đorđe Stanković spoke of a situation in which 'everyone was running away from "global scholarship" and satanically confining themselves to parochial mythologies', and the bookstores of Serbia were inundated with what Andrej Mitrović, Radivoj Radić and others called 'pseudohistory'. ${ }^{3}$ Others, particularly younger historians, sought a refuge of sorts by

Thanks to Emily Greble who commissioned this article, to Christian J. Bailey for sage advice and patience and to the anonymous reviewer and colleagues for very useful input.

1 Radomir J. Popović and Ana Stolić have produced a useful overview of the history of the prominent Historical Institute (Istorijski institut) in Belgrade, and Momčilo Pavlović has done the same for the Institute for Contemporary History (Institut za savremenu istoriju). Radomir J. Popović and Ana Stolić, 'Historijski institut 1947-2017. godine', Istorijski časopis, 66 (2017), 13-25; Momčilo Pavlović, 'Institut za savremenu istoriju, 1958-2008', Istorija 20. veka (2009), 9-17.

2 The examples that could be provided of this phenomenon are unfortunately numerous and by no means restricted to Serbia or Serbs. Two prominent examples are the historians Milorad Ekmečić and Vasilije Krestić. The former authored a number of important works in socialist Yugoslavia but became an advisor to the first president of Republika Srpska, Radovan Karadžić, who was convicted of genocide, war crimes and crimes against humanity at the United Nations' International Criminal Tribunal for the Former Yugoslavia (ICTY). The latter already in 1986 published notorious writings asserting that Croats were essentially genocidal. On the role of Serb intellectuals in the 1980s, see Jasna Dragović-Soso, 'Rethinking Yugoslavia: Serbian Intellectuals and the 'National Question' in Historical Perspective', Contemporary European History, 13, 2 (2004), 170-84; Jasna Dragović-Soso, 'Saviours of the Nation': Serbia's Intellectual Opposition and the Revival of Nationalism (London: Hurst, 2002).

3 Đorđe Stanković quoted in Mihael T. Antolović and Biljana Šimunović-Bešlin', History as Vallis Aurea: Đorđe Stanković and the Modernization of Serbian Historiography', Tokovi istorije, 3 (2018), 13; Andrej Mitrović, Raspravljanja sa Klio (Sarajevo: Svjetlost, 1991). Radivoj Radić, a historian of the Byzantine Empire criticized distortions of history in his hilariously entitled book, Serbs before Adam and after Him. Radivoj Radić, Srbi pre Adama i posle njega: Istorije jedne

(c) Cambridge University Press 2019 
studying or working abroad during the same period. ${ }^{4}$ Hence the historical profession cannot be divorced from the politics and wars of that awful decade.

This piece attempts to survey recent Serbian historiography by identifying and analysing major publications and developments. Together with my own review of the historiography, I rely on useful conceptual historiographical essays produced by historians in Serbia. ${ }^{5}$ Needless to say, it would be much too challenging and time consuming to examine all publications produced by Serbian historians in recent years, so this essay will of necessity be selective and subjective. ${ }^{6}$ The most obvious restriction involves periodisation; as a historian of the Balkans in the twentieth century, I have chosen to focus predominantly on works that cover this period. I commence with an overview of the tumultuous debates regarding the topics of resistance and collaboration during the Second World War. In addition, I cast a glance at the newer historiography of Serbia under communism. The article concludes with an overview of prominent and interesting publications on a wide array of other topics and with some general reflections about the state of Serbian historiography. As will be seen, many of these observations could also easily pertain to neighbouring Croatia and to other Yugoslav successor states.

Although I focus on the twentieth century, I have decided to exclude the Serbian historiography of the collapse of Yugoslavia and the ensuing wars. A number of historians in Serbia have engaged with this topic and continue to do so, but a survey of it and the attendant controversies would at a minimum require a separate article. ${ }^{7}$ My hope is that the present piece will succeed in acquainting a broader audience with significant newer trends and names in Serbian historiography as well as detailing the often pervasively politicised environment in which historians operate in Serbia. Finally, let me make it clear that in alignment with the Spotlight series in which it appears, the ambit of this essay is, with a few exceptions, restricted to recent historical works produced by historians working and publishing in Serbia, though references will also be made to a few works produced elsewhere. ${ }^{8}$ Let it also be stated clearly that I make no claim that the publications of foreign historians on Serbian history are superior to those of their colleagues in Serbia.

\section{Of Disintegration and Revisionism}

The disintegration of Yugoslav historiography was, like the process of the country's disintegration itself, a long one whose exact beginnings significantly predate the country's actual collapse in 1991. Ivo Banac, a Croat historian who taught at Yale University, wrote perhaps the most prominent essay regarding the demise of Yugoslav historiography. ${ }^{9}$ Banac pinpointed a gathering of Yugoslav historians in May 1979, one year before the death of Yugoslav President Josip Broz Tito, as the beginning of the end. As Tito's reign drew to a close, historians were among those who began to question the core

zloupotrebe, Second Edition (Belgrade: Stubovi kulture, 2005); Radivoj Radić, Klio se stidi: Protiv zlostavljanja istorijske nauke (Belgrade: Evoluta, 2016).

${ }^{4}$ Predrag J. Marković, Miloš Ković and Nataša Milićević, 'Developments in Serbian Historiography since 1989', in Ulf Brunnbauer, ed., (Re)Writing History: Historiography in Southeast Europe after Socialism (Münster: Lit Verlag, 2004), 286-92.

${ }^{5}$ Marković, Ković and Milićević, 'Developments', 277-316; Vladimir Petrović, 'Prilog proučavanje konstituisanja savremene istorije', Istorija 20. veka, 1 (2010), 167-81; Miroslav Jovanović, 'Savremena srpska istoriografija: Karakteristike i trendovi', Istorija 20. veka, 1 (2010), 183-92. Mile Bjelajac and his colleague Gordana Krivokapić criticise terms such 'Serbian historiography' and 'international historiography' (svetska istoriografija) as being reductionist, but also recognise their inevitability. Mile Bjelajac, 'Srpska istoriografija danas - tematski razgovori', Tokovi istorije, 1 (2018), 161-75.

${ }^{6}$ Miroslav Jovanović calculated that present-day historians in Serbia produce quantitatively more works than their colleagues did in the 1960s or 1970s. Miroslav Jovanović, 'Savremena srpska istoriografija: Karakteristike i trendovi', Istorija 20. veka (2010), 184.

7 Suffice it to say that Serb historians tend to treat the wars of Yugoslav succession as civil wars, whereas historians elsewhere, and particularly in Croatia and Bosnia-Herzegovina, speak of international or interstate wars.

8 The Contemporary European History Editorial Team, 'Spotlight Series', Contemporary European History, 27, 1 (2018), 110-1. Unless otherwise noted, the names referenced in this article are those of historians in Serbia.

9 Ivo Banac, 'Historiography of the Countries of Eastern Europe: Yugoslavia', The American Historical Review, 97, 4 (Oct. 1992), 1084-104. 
axioms of the Yugoslav state. A number of other scholars have also engaged with the topic of the role of historians in the collapse of Yugoslavia. ${ }^{10}$

Writing in 2019 one can perhaps still legitimately ask whether the end of the disintegrative process has been - or will ever be - reached. Historians of all countries which have been part of other state or imperial constructions - and Serbia has been through many such transformations - must struggle with how to process intellectually the legacies and meanings of predecessor states. ${ }^{11}$ After all, Serbia spent much more time in various forms of a Yugoslav state in the twentieth century than it did as an independent state. ${ }^{12}$ The tendency to ignore those areas of the predecessor states not encompassed by Serbia (and Kosovo) today - as Turkish historians long did with respect to the Ottoman Empire or to cast these predecessors as annoying (and annoyingly long-lasting) anomalies which merely served to delay the (return to the) allegedly natural condition of the nation state, is evident in much recent Serbian historiography.

More generally, Srđan Milošević has noted that 'Serbian historiography has no developed tradition of studying its own development'. ${ }^{13}$ Undoubtedly, the dramatic transitions and discontinuities afflicting Serbian history did not prove conducive to historiographical studies. All too often, the tendency after each transition was instead to cast the previous system's historical production (and some historians) on the landfill, a process that was sometimes accompanied by equally uncritical rehabilitation of the historical writings produced in the system preceding the discarded one. ${ }^{14}$ In this sense, the period since 1991 proved true to form. Yugoslavia's dissolution also led to an additional question: what should be done with the historians who inhabited the common Yugoslav state until 1991 and their own scholarly production, often produced in dialogue with colleagues in Serbia? Should one standard of scrutiny be applied to the work of ethnic Serbs - including those 'stranded' outside of Serbia - and another to those historians who are not Serbs - including those still residing in Serbia?

As in other formerly socialist countries, historians in Serbia in the late 1980s and early 1990s seized upon topics that had previously been deemed taboo or too controversial by the communist hierarchy, particularly as regards the Second World War. ${ }^{15}$ Predrag Marković, Miloš Ković and Nataša Milićević identified five developments that 'began to reshape the image of the recent past during the 1980s, and gathered momentum in the 1990s: a) the redefinition of the Četnik movement, b) new approaches to pre-communist Yugoslavia, c) the reinterpretation of Serb casualties of the Second World War, d) the rediscovery of communist repression and its victims after 1944, [and] e) the over-proportional role of non-academic "history-centred" writing (and thinking) in public life.' ${ }^{16}$

Though outright censorship had been rare in Yugoslavia in comparison to Eastern Bloc states, many historians had exercised self-censorship by consciously avoiding sensitive topics. Tamara Spasojević certainly exaggerates in claiming that research on Serb victims in the Second World War had been for decades a 'forbidden topic' and that Serbs were 'condemned to be quiet about such

10 See for example Norman Naimark and Holly Case, eds. Yugoslavia and Its Historians: Understanding the Balkan Wars of the 1990s (Stanford: Stanford University Press, 2003).

11 Zoltán Györe, 'Serbian Historiography and the Modern State', in James S. Amelang and Siegfried Beer, eds., Public Power in Europe: Studies in Historical Transformations (Pisa: Edizioni Plus, 2006), 89-108.

12 Three prominent historians addressed the Yugoslav legacy in an interview published on the centenary of the establishment of the Kingdom of Serbs, Croats and Slovenes. Interview with Bojan Dimitrijević, Momčilo Pavlović and Vladimir Petrović, 'Jugoslaviju je bilo lakše zamišljati nego ostvariti', Politika, 2 Dec. 2018.

13 Srđan Milošević, 'Kritički istoričar i društvo', in Latinka Perović, ed., Snaga lične odgovornosti (Belgrade, 2008 ), 203.

14 For critical overviews of how politics and historiography intertwined during earlier periods, see Đorđe Stanković and Ljubodrag Dimić, Istoriografija pod nadzorom (Belgrade: Službeni list SR Jugoslavije, 1996); Andrej Mitrović, Raspravljanja sa Klio (Sarajevo: Svjetlost, 1991).

15 On the changing interpretations of the Second World War, see Tamara Spasojević, 'Slika Drugog svetskog rata u časopisu 'Istorija 20. veka", Istorija 20. veka (2004), 105-31. One of the first revisionist articles which cast a positive light on Dragoljub 'Draža' Mihailović and the Chetnik movement was Kosta Nikolić, 'Prilog proučavanja karaktera ustanka u Srbiji 1941. godine', Istorija 20. veka (1991), 91-129.

16 Marković, Ković and Milićević, 'Developments', 282. 
killings in the name of preserving "brotherhood and unity"'. ${ }^{17}$ In some cases, these topics were tackled by young historians eager to make their mark, and undoubtedly a number of previously taboo topics deserved thorough historical scrutiny. However, as Spasojević has noted, some of these historians went to the opposite extreme and completely denigrated the 'People's Liberation Struggle' (Narodnooslobodilačka borba; NOB), the official Yugoslav communist term for the Second World War. Extensive research on Serb and other Second World War victims was conducted in socialist Yugoslavia, but the exploitation of victims and victimhood for nationalist gain was forbidden. ${ }^{18}$

Two of these developments were focused on the Second World War. In 2004 Spasojević delineated three phases of Second World War scholarship in Serbia from 1983 to $2001 .{ }^{19}$ In the first phase, from 1983 until 1991, historians did not challenge the party-state's interpretation of the struggle as nearly infallible and inviolable, though as interethnic tensions rose in the final years of Yugoslavia's existence the question of mass atrocities committed during the Second World War become more acute and politically relevant. Despite voluminous research in socialist Yugoslavia on the crimes committed by the quisling Independent State of Croatia (Nezavisna Država Hrvatska; NDH), Spasojević adheres to the view that this was among the forbidden topics and that 'Serbs were condemned to be quiet about this suffering because of the preservation of "brotherhood and unity"' ${ }^{20}$

The second phase, which lasted until 1997, witnessed the flourishing of historical research challenging previously held views. Particularly noteworthy was the rehabilitation of Dragoljub 'Draža' Mihailović and the Chetnik movement, which had initially enjoyed Allied support after the capitulation of Yugoslavia in 1941 but had disgraced itself through tactical collaboration with the Axis and mass atrocities committed against its opponents. Primarily thanks to the historians Bojan Dimitrijević and Kosta Nikolić, the Chetnik movement now came to be portrayed as an 'anti-fascist movement' on par with the Partisans. This marked a complete rebuke of the official socialist Yugoslav stance regarding the Chetniks as a traitorous and counterrevolutionary if not outright fascist movement. ${ }^{21}$ Conversely, historians cast a much more critical eye than previously on both Tito and the Partisan movement, raising amongst others the question of extrajudicial killings and mass reprisals committed by the Partisans at the end of and immediately following the Second World War. According to Jelena Đureinović, 'after the fall of Slobodan Milošević in 2000, the state devoted considerable effort in the field of the politics of memory, officially recognising the Chetniks of Dragoljub Mihailović as a national anti-fascist movement and often interpreting the end of the Second World War not as a victory and liberation, but instead through the politics of repression and victimisation on the part of the communist regime'. ${ }^{22}$ Đureinović observes that neglect and nationalist distortions of the Partisans paralleled the positive reevaluation of the Chetnik movement. Đorđe Stanković effectively skewered the weak factual basis of the rehabilitation of Mihailović. ${ }^{23}$

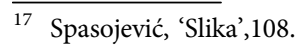

18 By contrast, as countless historians have noted, the socialist Yugoslav regime was of course perfectly capable of exploiting the 'People's Liberation Struggle' and its victims for political gain within the official ideological framework of socialist Yugoslavia.

19 Spasojević, 'Slika', 106-28. See also Dragan Aleksić, 'Izdajnici ili rodoljubi: Paralelna slika o kolaboraciji u srpskoj istoriografiji u zemlji i emigraciji', Istorija 20. veka (2010), 166-7.

20 Spasojević, 'Slika', 108.

21 Spasojević does however note that the eminent historian Branko Petranović already in 1983 described the Chetnik movement as 'the most significant antifascist phenomenon in the Serb bourgeoisie.' Branko Petranović quoted in Spasojević, 'Slika', 112

22 Jelena Đureinović, 'Historija, sećanja i pravo: još jedan osvrt na problem sudske rehabilitacije u Srbiji', Godišnjak za društvenu istoriju, 3 (2016), 89-112. On the broader questions raised by rehabilitation see Srđan Milošević, Istorija pred sudom: Interpretacija prošlosti i pravni aspekti u rehabilitaciji kneza Pavla Karađorđevića (Belgrade: 2013); Đorđe Stanković, 'Politička represija i rehabilitacija', Tokovi istorije, 1-2 (2009), 215-36.

23 Đorđe Stanković, 'Dihotomija istorijske nauke u Srbiji', Tokovi istorije, 4 (2006), 232-33; Jelena Đureinović, The Politics of Memory of the Second World War in Contemporary Serbia: Collaboration, Resistance and Retribution (London: Routledge, forthcoming). 
The previously taboo topic of the brutal repression of pro-Cominform communists on the prison island Goli Otok also attracted research. And in addition to the rehabilitation of Mihailović, historians in Serbia in the 1990s devoted much greater attention than previously to the genocide perpetrated against Serbs in the NDH. Unfortunately, in part reacting to widespread denial of these crimes in contemporary Croatia, some of this scholarship veered into a ghastly and myopic obsession with the numbers of victims - the so-called 'numbers game'. 24

Finally, in the third phase after 1997, spurred on by the deteriorating situation in Kosovo, many historians moved away from the Second World War and on to other topics, particularly Kosovo and Serbo-Albanian relations. The fact that this revisionism took place against the background of extreme antagonism between Serbs and Albanians, culminating in the Kosovo War of 1998-9 and the eventual and still contested independence of Kosovo, already speaks sufficiently of the motivation for much of this historiography.

Bojan Dimitrijević, who has written extensively about the Serbian royalist Ravna Gora (Chetnik) movement during the Second World War, has identified the following topics which received 'new interpretations' during the 1990s: the history of Serbia under occupation, the history of the Ravna Gora movement and its leader, Dragoljub Mihailović, the collaborationist Nedić regime, the so-called Independent State of Croatia, concentration camps. ${ }^{25}$ As already noted, the engagement with such topics did not take place in a vacuum. Dimitrijević himself notes that 'historians have become much more present in the media', and their findings have been disseminated also through history textbooks for primary and secondary schools, which have been extensively rewritten. Another consequence has been the Serbian state's decision to extend the same veterans' rights to veterans of the Chetnik movement which were previously only available to veterans of the communist-led Partisan movement.

Very broadly put, the new generations of historians in Serbia in the 1990s were engaged in revisionism with respect to much of twentieth-century history. ${ }^{26}$ To quote Vladimir Petrović, in the former Yugoslavia (and in other post-socialist societies), 'revisionism plays the role of the bogeyman, but also has the allure of fruit forbidden until yesterday. On the one hand, it is used as a label to devaluate scholarly contributions, on the other hand as a plume to legitimate pseudo-historiography.'27 There was of course nothing inherently wrong about assuming a critical stance with respect to socialist historiography. The problem arose when the critical stance was replaced by a wholesale rejection of the previous historiography and by a rather uncritical and nationalist stance.

In still other cases, older historians who had previously written more or less dogmatically about these topics in previous decades produced new publications which substantially revised or even

24 For critical views regarding this obsession, see Bette Denich, 'Dismembering Yugoslavia: Nationalist Ideologies and the Symbolic Revival of Genocide', American Ethnologist, 21, 2 (1994), 367-90; David Bruce MacDonald, Balkan Holocausts? Serbian and Croatian Victim-Centered Propaganda and the War in Yugoslavia (Manchester: Manchester University Press, 2002); Đorđe Stanković, 'Srpska medijalna kultura sećanja', Tokovi istorije, 3 (2006), 274-5.

25 Bojan Dimitrijević, 'Epoha pomeranja istoriografskih saznanja i optužbe za 'revizionizam”, Istorija 20. veka, 2 (2015), 183-8. See Bojan Dimitrijević and Kosta Mihailović, Đeneral Mihailović: Biografija (Belgrade: Srpska reč, 2000).

26 On historical revisionism in the former Yugoslavia, see Revizija prošlosti na prostorima bivše Jugoslavije (Sarajevo, Institut za istoriju u Sarajevu, 2007); Darko Karačić, Tamara Banjeglav and Nataša Govedarica, Re:Vizija prošlosti: Politika sjećanja u Bosni i Hercegovini, Hrvatskoj i Srbiji od 1990. godine (Sarajevo, 2012); Drago Roksandić, Historiografija u tranziciji (Zagreb: Srpsko kulturno društvo 'Prosvjeta', 2018).

27 Vladimir Petrović, '(Ne)legitimni revizionizam: Pravo i (pseudo)istoriografske revizije na zapadu i istoku', in Vera Katz, ed., Revizija prošlosti na prostorima bivše Jugoslavije (Sarajevo: Institut za istoriju, 2007), 21. Of course, Serb historians also can and do accuse not just each other but also foreign colleagues of engaging in revisionism - in the pejorative sense of that term. Aleksandar P. Rastović has assailed the First World War histories produced by Christopher Clark and Margaret MacMillan. Aleksandar P. Rastović, 'Srbi, Rusi i Prvi svetski rat - jedan primer revizije istorije', Istorijski časopis, 64 (2015), 363-74; Mile Bjelajac, 'Novi (stari) zapleti oko uzroka Prvog svetskog rata pred obeležavanje 100. godišnjice, Tokovi istorije, 1 (2013), 15-62; Mile Bjelajac, 1914-2014: Zašto revizija? Stare nove kontroverze o uzrocima Prvog svetskog rata (Belgrade: Odbrana, 2014). See also Mira Radojević and Ljubodrag Dimić, Srbija u Velikom ratu, 1914-1918: Kratka istorija, $3^{\text {rd }}$ Edition (Belgrade: Beogradski forum za svet ravnopravnih, 2016). 
contradicted their previous findings and adopted a nationalist straitjacket - often without even acknowledging this volte-face. For example, the historian Branislav Gligorijević during his long career produced solid articles about interwar Yugoslav history written from a Marxist perspective. However, at the end of his career, he produced a three-volume biography of King Aleksandar Karađorđević which, while serviceable, fundamentally contradicted much of Gligorijević's earlier writings. ${ }^{28}$

In addition to scholarly production, historians in Serbia have been involved in the rehabilitation of leading figures from the Second World War through courtroom testimony as expert witnesses as well as in the work of state commissions established to identify victims of both official executions and extrajudicial killings in Serbia during the last year of the war and in the immediate post-war period. ${ }^{29}$ To a significant extent, the historians working on these commissions regard any executions or other punishments meted out towards collaborationists as illegitimate and legally void. ${ }^{30}$ Indeed, Dimitrijević even seems to reject or at least relativise the very notion of collaboration with Axis forces, suggesting that what he calls the 'so-called memory culture is, in essence, a sick and personal relation towards the past'. ${ }^{31}$ The priority instead is placed on how the Chetnik movement acted out of a laudable primary concern for the survival Serb nation, shunning direct confrontation of the Axis (and in particular German) forces in order to avoid bloody reprisals. Any participation of Serbs as collaborators or perpetrators in the Holocaust is also questioned. Criticism of the Chetniks' atrocities or extreme nationalist ideology is by contrast dismissed as being ahistorical and decontextualised.

As a corollary, in Serbia and elsewhere in the former Yugoslavia, historians influenced by contemporary politics have questioned or even openly denigrated the once hallowed notion of 'anti-fascism'. Indeed, some claim that this term is some kind of communist Yugoslav invention without any relevance or traction outside of the former Yugoslavia. ${ }^{32}$ Bojan Dimitrijević goes the furthest, calling anti-fascism an overly broad term advocated by a coalition ranging from 'nostalgic leftist intellectuals through defeated communists to perverted [izopačeni] sexual groups' ${ }^{33}$ By contrast, Jelena Đureinović states that, 'in the context of Serbia, the revival of collaborationist movements has the goal of switching value systems: anti-fascism should be discarded as a struggle for power and as a communist crime, and collaboration should be socially accepted as the defence of the nation and as a legitimate struggle against communism, ${ }^{34}$ Olga Manojlović-Pintar has also criticised the relativisation of the terms collaboration, fascism and anti-Semitism, claiming that 'it has come to an absurd equation of the ideologies of socialism and fascism. In this manner contemporary nationalist narratives have been constituted. ${ }^{35}$

28 Branislav Gligorijević, Aleksandar Karađorđević: Ujedinjenje srpske zemlje, Vol. 1 (Belgrade: BIGZ, 1996). See also Dragoljub Živojinović's trilogy about King Aleksandar's father, Petar Karađorđević. Dragoljub Živojinović, Kralj Petar I Karađorđević, 3 vols. (Belgrade: BIGZ, 1988-1994).

29 Milivoj Bešlin, 'Istorijsku istinu ne bi trebalo da utvrđuje sud', Novi Magazin, 424, 13 June 2019; Jelena Đureinović, 'Historija', 106-7; Tomislav Dulić, 'Osuđen 'iz ideoloških i političkih' razloga? Rehabilitacija Dragoljuba 'Draže' Mihailovića u Srbiji', Sociologija, 4 (2012), 625-48.

30 For various views on the term 'collaboration', and in particular regarding how views held by anti-communist Serb emigres seeped into Serbian historiography, see Dragan Aleksić, 'Izdajnici ili rodoljubi: Paralelna slika o kolaboraciji u srpskoj istoriografiji u zemlji i emigraciji', Istorija 20. veka, 2 (2010), 163-74.

31 Bojan Dimitrijević, 'Epoha pomeranja istoriografskih saznanja i optužbe za 'revizionizam”, Istorija 20. veka, 2 (2015), 185. It is worth noting that also condescendingly refers to nongovernmental organisations which work on human rights issues. As will be seen, this may well be in part because a number of historians critical of Dimitrijević have published their essays with the Serbian Helsinki Committee. Dimitrijević has also written positively about Ratko Mladić, the commander of the Bosnian Serb army convicted of genocide, war crimes and crimes against humanity by the UN International Criminal Tribunal for the Former Yugoslavia. Bojan Dimitrijević, Komandant: Knjiga o Mladiću (Belgrade: Vukotić media, 2018).

32 On disputes in Serbia regarding 'anti-fascism', see Todor Kuljić, 'Anti-antifašizam', Godišnjak za društvenu istoriju, 1-3 (2005), 171-84; Zoran Janjetović, 'Odgovor Srđanu Miloševiću’, Tokovi istorije, 1 (2014), 249-54; Jelena Subotić, Yellow Star, Red Star: Holocaust Remembrance after Communism (Ithaca: Cornell University Press, forthcoming). The fact that Contemporary European History devoted an entire issue $(25,4,2016)$ to transnational anti-fascism amply illustrates that this term is neither empty nor limited to the former Yugoslavia.

33 Dimitrijević, 'Epoha', 187.

34 Đureinović, 'Historija', 94.

35 Olga Manojlović-Pintar, 'O revizijama, dijalozima i kulturi sećanja', Tokovi istorije, 1-2 (2009), 209. 
The term 'revisionist' is frequently deployed in the polemics of historians in Serbia, usually with an expressly pejorative connotation. Revising history is of course part and parcel of the routine work of professional historians. While serving as president of the American Historical Association, James McPherson rightly called revisionism 'the lifeblood of historical scholarship. History is a continuing dialogue, between the present and the past. Interpretations of the past are subject to change in response to new evidence, new questions asked of the evidence, new perspectives gained by the passage of time. ${ }^{36}$ To be more precise, it is therefore not revisionism per se that is problematic, but rather what the sociologist Todor Kuljić defines as 'the processing of the past which is informed by clear or concealed intentions to justify narrow national or political goals' ${ }^{37}$ Revisionism with respect to the Second World War in Serbia can take several different forms. As Kuljić (citing historian Wolfgang Wippermann) observes about revisionism with respect to the Holocaust, there is 1 . outright denial, 2. relativisation of crimes and 3. recognition of crimes combined with what is increasingly being called 'whataboutism'. Often revisionism is (barely) disguised with seemingly reasonable assertions or requests such as 'it is too early to state with certainty what occurred' or 'further research is needed'.

Even more specifically in the context of recent historiography in Serbia, we can identify revisionist works as those which for ideological reasons aim to rehabilitate historical figures and movements associated with the Second World War while either completely denying or extensively downplaying the crimes for which they were earlier deemed responsible. These earlier findings of responsibility in turn stem from both the intensely problematic post-war trials of collaborationists and from the historiography of socialist Yugoslavia. Much recent Serbian historiography on collaborationist movements and leaders during the Second World War commits the basic fallacy of assuming that because these movements were oppressed by a communist regime that itself committed war crimes and human rights violations, the aforementioned movements and leaders must be innocent. In this view, all victims of extrajudicial killings in 1944-5, as well as anyone tried and convicted by a communist court in Yugoslavia, particularly during the Stalinist phase (1945-53), must be guiltless.

To condemn Stalinist trials from the immediate post-war era is one thing. To propose that the majority of historical scholarship conducted in socialist Yugoslavia be discarded as entirely invalid or to insist on the absolute innocence of wartime collaborators is an entirely different matter. ${ }^{38}$ It is understandable for a historian such as Tamara Spasojević to write that 'we must not place ourselves in the role of a prosecutor or defender, but should instead through objective and many-sided research arrive at the truth' regarding the most controversial figures in Serbian history. ${ }^{39}$ However, the reality is that some Serb historians have unfortunately become not only vocal defenders and rehabilitators of figures such as Dragoljub Mihailović and Milan Nedić, but have also excelled in denying their crimes and those of their followers. This is particularly worrying in the context of contemporary Serbia, where some political parties and organisations openly idolise these figures. Revisionist historians in Serbia and in the region as a whole would do well to heed the words of the American historian of Yugoslavia Fred Warner Neal, who already in the 1950s warned that 'anti-communism by itself is not a substitute for scholarship, ${ }^{40}$ Moreover, there is a certain irony that many of those historians who reject Yugoslav historiography produce even more ideologically rigid and politicised works than those of the 1960s, 1970s and 1980s.

\footnotetext{
36 James McPherson, 'Revisionist Historians', Perspectives (Sept. 2003), https://www.historians.org/publications-and-directories/perspectives-on-history/september-2003/revisionist-historians.

37 Todor Kuljić, Prevladavanje prošlosti: Uzroci i pravci promene slike istorije (Belgrade: Helsinški odbor za ljudska prava u Srbiji, 2002), no pagination.

38 Srđan Milošević notes regretfully that in the 1990s much existing historiography was dismissed as being allegedly 'Comintern, Vatican, Judeo-Masonic, in any case anti-Serbian and unpatriotic'. Milošević, 'Kritički istoričar', 232.

39 Tamara Spasojević, 'Slika', 123.

40 Fred Warner Neal, Review of Jozo Tomasevich's Peasants, Politics and Economic Change in Yugoslavia in The American Slavic and East European Review, 15, 2 (Apr. 1956), 286-8. Neal believed that Tomasevich deftly avoided falling into this trap.
} 
On the opposite side of the spectrum, a number of historians such as Dubravka Stojanović, Olga Manojlović-Pintar and the late Olga Popović-Obradović joined forces with the venerable Latinka Perović to produce research which takes a very critical and even negative view of the course of Serbian history in the twentieth century. ${ }^{41}$ Notably, many of their critiques have been published by the Serbian Helsinki Committee, which also continues to publish critical historical monographs. ${ }^{42}$ That one of Serbia's leading human rights organisations should also be a frequent publisher of historical works may at first glance puzzle outsiders. However, taking into consideration the politicisation and abuses of history under the Milošević regime and the continuing struggles to define the trajectory of the Serbian state and nation, the role of the Serbian Helsinki Committee becomes more understandable. ${ }^{43}$

Another prominent critic of revisionism in recent Serbian historiography was the late Đorde Stanković, who for many years headed the history department at the University of Belgrade. In 2008 Stanković pointed out that a number of the collaborationist figures being rehabilitated had implicated themselves in the commission of war crimes. For example, it was not 'leftists' who claimed that the famous Serb lawyer Slobodan Jovanović had signed documents that led to the execution of numerous Serbs during the war, but rather Milan Nedić and his associates who had provided confirmation. ${ }^{44}$ Stanković also provided several quotes that illustrated beyond any doubt the faith that Nedić placed in the new order promised by Hitler.

Arguably one of the underlying causes of nationalist revisionism - and one of the most persistent problems in the historiography of Serbia and its former Yugoslav neighbours - is the phenomenon of competitive collective victimhood. ${ }^{45}$ In a region which every bit as much as Timothy Snyder's now famous 'bloodlands' witnessed a twentieth century in which every state and every nation became victims - often repeatedly - of organised mass violence and authoritarian regimes, victimhood is oversaturated. ${ }^{46}$ Historical research into war, crimes and victimhood is undoubtedly necessary, but all too often the narratives of collective victimhood reveal an obsession with the group rivalled only by a disinterest in the individual humanity of the victims, who are symbolically thrust forward as a justification for the group's past suffering and present and future claims. And articles on one's own victims far outnumber those written about one's own perpetrators or the victims of the 'Other'. It is unfortunately still relatively difficult to imagine that anyone would write an article about Serbian crimes in Kosovo that would complement Nenad Antonijević's article on Kosovo Albanian crimes. ${ }^{47}$ Moreover, all too often historians' writings on these topics in Serbia fail what could be called the 'reverse applicability test'. To wit: if the arguments and logic applied in a given analysis of a historical event were instead

$\overline{41}$ Olga Popović-Obradović, Parlamentarizam u Srbiji, 1903-1914. (Belgrade: Službeni list, 1998); Latinka Perović, Između anarhije i demokratije: Srpsko društvo na prelazima vekova (Belgrade: Helsinški odbor za ljudska prava u Srbiji, 2006).

42 The magazine of the Serbian Helsinki Committee is called Helsinške povelje. The Committee recently published a monograph featuring prominent historians from throughout the former Yugoslavia and translated it into English. Sonja Biserko, ed., Yugoslavia in Historical Perspective (Belgrade: Helsinki Committee for Human Rights in Serbia, 2017). See also Dubravka Stojanović, Novosti iz prošlosti: Znanje, neznanje, upotreba i zloupotreba istorije (Belgrade: Beogradski centar za ljudska prava, 2010).

43 A comparison may be made to the organisations Documenta in Croatia and Memorial in Russia. See Miguel Vázquez Liñán, 'History as a propaganda tool in Putin's Russia', Communist and Post-Communist Societies, 43, 2 (June 2010), 167-78.

44 Đorđe Stanković, 'Mandala ili kultura sećanja i 'rehabilitacije", Hereticus, 2 (2008), 232.

45 Christian Axboe Nielsen, 'Collective and Competitive Victimhood as Identity in the Former Yugoslavia', in Nanci Adler, Understanding the Age of Transitional Justice: Crimes, Courts, Commissions, and Chronicling (New Brunswick: Rutgers University Press, 2018), 175-93. See also Jelena Subotić, 'Stories States Tell: Identity, Narrative and Human Rights in the Balkans', Slavic Review, 72, 2 (Summer 2013), 306-26.

46 Timothy Snyder, Bloodlands: Europe between Hitler and Stalin (New York: Basic Books, 2010).

47 Nenad Antonijević, 'Albanski zločini nad Srbima na Kosovu i Metohiji u periodu jun-oktobar 1999', Istorija 20. veka, 1 (2008), 157-65. Research in Serbia into crimes committed by Serbs during the wars of Yugoslav succession remains largely confined to non-governmental organisations specialising in human rights and transitional justice. It should be noted that such research incurs considerable hostility, and that some public lectures and events regarding these issues have been disrupted by right-wing extremists. 
utilised by a Croat, Bosniak or (Kosovo) Albanian scholar to describe a historical event, would it be acceptable to a Serb historian? To be clear, many articles written in neighbouring countries would fail this test as well. Surely it must be possible to describe the crimes of others without denying or relativising the crimes of one's own?

The interlinked and still often mutually antagonistic nature of Serbian and Croatian historiography of the twentieth century can be illustrated by examining the reactions of historians in Serbia to the equally worrying wave of revisionism that has recently afflicted Croatia. ${ }^{48}$ Popular, officially funded tabloids obsessed with irrelevant and sordid trivia, publicists and amateur historians who sensationalise and trivialise mass atrocities and other dark episodes in twentieth-century Serbian and Yugoslav history significantly exacerbate this problem. So do various historical documentaries and dramas which have been aired on Serbian television, and which have contributed to the popular rehabilitation of controversial figures - and to the demonisation or humiliation of others - in modern Serbian history. ${ }^{49}$ And Dubravka Stojanović has frequently and eloquently criticised the content and tone of history textbooks published in Serbia since $1990 .^{50}$

At the worst of times, nationalist historians in Croatia and Serbia seem to be engaged in 'shouting matches', though some strange bedfellows have also emerged, as in the collegial relationship of Bojan Dimitrijević and the nationalist and revisionist Croat historian Zlatko Hasanbegović. ${ }^{51}$ Historians in Serbia are correct to view with great concern and dissatisfaction contemporary attempts by their colleagues in Croatia to relativise the systematic mass violence perpetrated by the NDH during the Second World War. Revisionism in Croatia has included the naming of streets after prominent figures from the NDH and an organised public campaign to whitewash the key Ustaša chant ' $z a$ dom spremni' roughly equivalent to 'Sieg heil' - by claiming that it is an older historical expression that is not inextricably linked to the NDH. Similarly, many of the same historians in Serbia who have accepted or supported the legal and historical rehabilitation of figures such as Mihailović and Nedić have stated their opposition to the beatification and possible canonisation of Archbishop Alojzije Stepinac, whom the communists in November 1946 convicted of collaboration.

It also seems that a problematic teleology still underlies much of Serbian historiography in the form of an assumption that the 'natural' end state of history is the establishment of a robust nation state. In this deterministic view, the Ottoman Empire and the Habsburg Empire appear as anational aberrations that have deterred and delayed Serbia's greatness. ${ }^{52}$ In the twentieth century Yugoslavia replaced the aforementioned empires as the next obstacle to the realisation of the nation state of the Serbs. In the dominant nationalist interpretation which emerged in the course of the 1980s, the Serbs selflessly sacrificed the existing Kingdom of Serbia for a South Slavic state in which the other nations behaved ungratefully and treacherously. This alleged folly was perpetrated again in socialist Yugoslavia, leading Dobrica Cosić to quip famously that Serbia won its wars but ended up losing the peace. Ćosić also propagated a narrative according to which the tragedy of the Serbs was the disunity caused by the

48 In the 1990s the Friedrich Naumann Foundation provided funding for a series of encounters between a diverse group of Serb and Croat historians that were designed to encourage dialogue and reconciliation. Four volumes resulted from this venture, but it should be noted that many of the historians participating stuck stubbornly to their sometimes nationalist understandings of historical writing. Marković, Ković and Milićević, 'Developments', 291-2.

49 Đorđe Stanković, 'Dihotomija istorijske nauke u Srbiji', Tokovi istorije, 4 (2006), 222, 230; Đorđe Stanković, 'Srpska medijalna kultura sećanja', Tokovi istorije, 3 (2006), 265-83.

50 Dubravka Stojanović, 'Serbia: History to Order', Transitions Online, 20 Mar. 2007; Dubravka Stojanović, 'Mitotvorna slika prošlosti', Helsinška povelja (Sept.-Oct. 2000), 45-8; Dubravka Stojanović, 'Nastava istorije kao predvojnička obuka', Reč, 83:29 (2013), 247-56.

51 Hasanbegović, who has authored a noteworthy book on the interwar Yugoslav Muslim Organization, served briefly as Minister of Culture in Croatia in 2016. He has publicly taken strongly nationalist and revisionist positions with respect to the Second World War quisling Independent State of Croatia. For an example of a 'shouting match', the summary of the exchange between Josip Pečarić and Milan Bulajić in Ivo Goldstein and Goran Hutinec, 'Neki aspekti revizionizma u hrvatskoj historiografiji devedesetih godina XX. stoljeća - motivi, metode i odjeci', in Revizija, 2007, 197.

52 Christian Axboe Nielsen, “Whoever Says That Serbia Is Small Is Lying!': Serbia, Ontological (In)Security and the Unbearable Smallness of Being' (forthcoming). 
political division of the Serb nation between communist Partisans and royalist Chetnik forces during the Second World War. ${ }^{53}$ In both Croatia and Serbia the theme of 'national reconciliation' weighed prominently in the 1990s.

It can be said that the most active revisionists in Serbia display a tendency to depict any political movements and figures that opposed communism as virtuous, even when these movements or figures were inherently antidemocratic, fascist and/or extensively collaborated with Axis forces during the Second World War. However, matters are not made better by the willingness of some scholars on the left to depict anti-fascist movements and leaders as immaculate because they opposed fascism, and to deny or downplay the crimes committed by the repressive organs of socialist Yugoslavia.

\section{Escaping the Gladiators' Arena: Towards Better and Broader Historical Research}

Plenty of historians in Serbia share the dismay of their foreign colleagues at the staid and repetitive research and the heated, ethnocentric and politicised polemics which all too often have characterised the treatment of the most popular topics of twentieth-century history. To paraphrase Iryna Vushko's and Elidor Mëhilli's articles in this journal on Ukrainian and Albanian historiography, too many questions being asked are old, prolong 'tedious polemics', or lead to dead ends, little new knowledge results and political history dominates. ${ }^{54}$

Consciously or not, tired of the 'here we go again' feeling, many historians have chosen to avoid these questions and the gladiator fights they occasion in favour of a wide array of other interesting and relatively neglected historical topics. I have over the years spoken to a number of younger historians in Serbia and neighbouring countries who have told me that they have deliberately avoided topics such as fascist and communist crimes because too many of their colleagues pursue these topics through exclusively ideological motives. Although not making quite as drastic a retreat those Eastern European and Soviet historians who after the Second World War withdrew to the cloisters of medieval history in order to try to avoid Marxist-Leninism dogmatism, these historians have discovered that steering away from world wars, oppression and mass atrocities provides peace of mind and opens up new horizons. ${ }^{55}$

The tables of contents of the most prominent Serbian historical journals Istorija XX. veka (History of the Twentieth Century), Godišnjak za društvenu istoriju (Yearbook for Social History) and Tokovi istorije (Currents of History) abound with a wide variety of important topics. ${ }^{56}$ Perusing the most recent decade of these journals as well as recent monographs reveals articles and books about diverse topics including the labour movement, Yugoslav foreign relations and participation in international organisations, migration and Gastarbeiter, the Non-Aligned Movement, Yugoslav volunteers in the Spanish Civil War, ethnic minorities, family and private life, science and technology, public health, religion, urbanisation, education, architecture, film and gender and sexuality, economic and industrial history. Much of this diversification of topics can be traced back to the creation of first the aforementioned Godišnjak in 1994 by Andrej Mitrović and Milan Ristović and then the Udruženje za društvenu istoriju (Association for Social History) in 1998. Mitrović's essay in the inaugural number of the Godišnjak was a heartfelt plea in a time of extreme isolation and nationalism for a Serbian historiography that would be multidisciplinary, innovative, multifaceted and open to dialogue with foreign colleagues. ${ }^{57}$

\footnotetext{
53 For a recent Croatian reiteration of this thesis, see Slaven Letica, 'Može li Hrvatska u miru izgubiti dobivene ratove', Večernji list, 15 Sept. 2017.

54 Iryna Vushko, 'Historians at War: History, Politics and Memory in Ukraine', Contemporary European History, 27, 1 (2018), 119; Elidor Mëhilli, 'Documents as Weapons: The Uses of a Dictatorship's Archives', Contemporary European History, 28, 1 (2019), 84.

55 In Belgrade after the Second World War 'nobody dared to teach contemporary history' until 1958. Marković, Ković and Milićević, 'Developments', 278.

56 Milan Gulić 'Trideset godina časopisa 'Istorija 20. veka', 1983-2013.', 2 (2013), Istorija 20. veka, 219-31.

57 Andrej Mitrović, 'Skica predloga za raspravljanje o proučavanju istorije društva', Godišnjak za društvenu istoriju, 1 (1994), $5-7$.
} 
Space constraints prohibit me from listing notable works on all the above topics, but I would like to shine the spotlight on some of the most exciting research contributions of recent years. Vladan Z. Jovanović has delved deeply into the history of Serbia and Yugoslavia's rule of interwar Macedonia and Kosovo - formerly known as Old or Southern Serbia - casting a much more critical light on the colonial and nationalist ambitions which Belgrade projected onto this area. ${ }^{58}$ More recently, Jovanović has also expanded into the fascinating history of the opium trade and the criminal underworld in the interwar Balkans. ${ }^{59}$ Vladimir Petrović has published an overview of the concept of 'ethnic cleansing', in which he also examines the unfortunate recurrence of the phenomenon in Balkan, Yugoslav and Serbian history. ${ }^{60}$ Moving back to the interwar period, Ivana Dobrivojević-Tomić has produced compelling work on repression and the dictatorship of King Aleksandar. $^{61}$

In the field of gender and women's history, great strides have been made during the past decades. ${ }^{62}$ Neda Božinović wrote a pioneering book about women in Serbian history. ${ }^{63}$ Vera Gudac-Dodić has written about women's education. ${ }^{64}$ Ivana Pantelić has looked at the emancipation of women both in the interwar period and after the Second World War, and has also written a monograph on Jovanka Broz, the 'first lady' of socialist Yugoslavia. ${ }^{65}$ Zorana Simić has examined the charitable organisation the Circle of Serb Sisters (Kolo srpskih sestara) ${ }^{66}$ Latinka Perović has edited a volume about women and modernisation and Milan Ristović has edited another volume on family and private life. $^{67}$ Sanja Petrović-Todosijević has written on public health and education. ${ }^{68}$

Srđan Cvetković has done much to uncover the scope of communist repression in Serbia. ${ }^{69} \mathrm{He}$ has not only been involved in producing scholarship, but also in identifying the location of previously secret graves of the victims of early communist extrajudicial killings.

58 Vladan Z. Jovanović, Jugoslovenska država i južna Srbija, 1918-1929; Vardarska banovina, 1929-1941; 'Tokovi i ishod međuratne kolonizacije Makedonije, Kosova i Metohije', Tokovi istorije, 3 (2006), 25-44.

59 Vladan Z. Jovanović, 'Makedonski opijum 1918-1941: O finansijskim i političkim razmerama fenomena', Godišnjak za društvenu istoriju, 3 (2009), 69-79; 'Ilegalni putevi jugoslovenskog opijuma između dva svetska rata', Godišnjak za društvenu istoriju, 3 (2016), 65-88; 'Skopska fabrika alkaloida braće Ognjanović', Tokovi istorije, 2 (2018), 67-88.

60 Vladimir Petrović, Etničko čišćenje: Geneza koncepta (Belgrade: ISI, 2019).

61 Ivana Dobrivojević-Tomić, Državna represija u doba diktature Kralja Aleksandra (Belgrade: Institut za savremenu istoriju, 2006); Ivana Dobrivojević-Tomić, 'Sudstvo i sudije u doba šestojanuarskog režima kralja Aleksandra (1929-1935)', Tokovi istorije, 3-4 (2005), 28-53.

62 For a useful overview of the broader literature on gender until 2003, see Biljana Dojčinović, Jelena Aranđelović et al., 'Annotated Bibliography of Journals and Books on Gender Issues in Serbia, 1991-2003', Knjiženstvo, 8 (2018), $197-225$.

63 Neda Božinović, Žensko pitanje u Srbiji u 19. i 20. veku (Belgrade: Devedesetčetvrta, 1996).

64 Vera Gudac-Dodić, 'Školovanje žena u Srbiji (1945-1991)', Tokovi istorije, 3 (2006), 90-104.

65 Ivana Pantelić, 'Neki aspekti položaja žena u Kraljevini Jugoslaviji', Knjiženstvo, 1 (2011), 215-26; Ivana Pantelić, Partizanke kao građanke: Društvena emancipacija partizanki u Srbiji, 1945-1953. (Belgrade: ISI, 2011); Ivana Pantelić, 'Osvajanje neosvojivog: politička emancipacija žena u posleratnoj Jugoslaviji 1945-1953.', Istorija 20. veka, 3 (2012), 139-54; Ivana Pantelić, Uspon i pad 'prve drugarice’ Jugoslavije: Jovanka Broz i srpska javnost 1952-2013 (Belgrade: Službeni glasnik, 2018).

66 Zorana Simić, 'Jelena Dimitrijević, Kolo srpskih sestara i kalendar Vardar (1906-1914; 1921-1941)', Knjiženstvo, 8 (2018), 60-79.

67 Latinka Perović, ed. Srbija u modernizacijskim procesima 19. i 20. veka: Položaj žene kao merilo modernizacije (Belgrade: Institut za noviju istoriju Srbije, 1998); Milan Ristović, ed., Privatni život kod Srba u dvadesetom veku (Belgrade: Clio, 2007)

68 Sanja Petrović Todosijević, ‘(Dis)kontinuitet bez presedana: Zdravstvena politika jugoslovenske države u prvoj polovini 20. veka', Tokovi istorije, 3 (2007), 96-119. Sanja Petrović Todosijević, 'Zdravstveno prosvećivanje naroda kao deo borbe za smanjenje smrtnosti dece u FNRJ', Istorija 20. veka, 2 (2005), 101-13; Sanja Petrović Todosijević, Otećemo svetlost bučnom vodopadu: Reform osnovnoškolskog sistema u Srbiji, 1944-1959 (Belgrade: INIS, 2018).

69 Srđan Cvetković, Između srpa i čekića 1: Likvidacija 'narodnih neprijatelja', 1944-1953., $2^{\text {nd }}$ Edition (Belgrade: Službeni glasnik, 2015); Srđan Cvetković, Između srpa i čekića 2: Politička represija u Srbiji, 1953-1985. (Belgrade: Službeni glasnik, 2011); Srđan Cvetković, Između srpa i čekića 3: Oblici otpora komunističkom režimu u Srbiji, 1944-1991. (Belgrade: Službeni glasnik, 2013); Srđan Cvetković, 'Politička represija u Srbiji i Jugoslaviji 1944-1985', Istorija 20. veka, 2 (2008), 299-343. 
Conversely, a number of scholars have explored the non-repressive dimensions of the socialist era. A prime example of this is Radina Vučetićs highly informative book on the Americanisation of Yugoslav popular culture. ${ }^{70}$ Vučetić has also written about censorship and culture in socialist Yugoslavia. ${ }^{71}$ This type of research interest interconnects with the exhibits and publications of the Museum of Yugoslavia (Muzej Jugoslavije) in Belgrade. ${ }^{72}$ Research like this can to some extent be seen as a reaction to those works of - overwhelmingly political - history that tend to render very negative portraits of position of Serbia and Serbs in socialist Yugoslavia. However, compared to Croatia and some Central European countries, the more nuanced works on life during the socialist period does not seem so far to have elicited such strongly negative and polemical reactions. It would be laudable if historians in Serbia could avoid the problematic but still strangely pervasive assumption that dealing with non-repressive aspects of life under communism is somehow tantamount to a negation of repression under the communist party-state. Finally, also particularly noteworthy as a contribution to transnational history is Vladimir Ivanović's solid overview of the so-called guest workers (Gastarbeiter) who left Yugoslavia to find work in West Germany and Austria. ${ }^{73}$

\section{Conclusion}

By way of rounding out this article, I should also like to point out a few notable developments in the Serbian historical profession which my colleagues have highlighted in our discussions in recent years. Serbian historians' increased use of archives outside Serbia, including outside of the former Yugoslavia, is a welcome development. Equally positive is the striving of these historians to try to present their findings in a broader context which draws inspiration from, interacts with and reacts to works in other European and even non-European historiographies. This also means an increase in the appearance of Serbian historians at international conferences and workshops to present their research, although not all historians engage equally in this process. For a number of younger historians, mirroring the situation of many other young people in Serbia and neighbouring countries, a mixture of socioeconomic and political push and pull factors lead them to pull up the stakes and emigrate, where quite a few of them launch successful international research careers. These historians can together with foreign colleagues specialising in the Balkans help build bridges, ensuring that the historiography of Serbia and the broader region is informed by constructive dialogue. On the publication front, the number of foreign historians who publish in major Serbian historical journals continues to be very small, as these journals are not seen as being significantly prestigious outside the region. Conversely, relatively few historians residing in Serbia - as opposed to those who have left Serbia publish in international peer-reviewed history journals. ${ }^{74}$ It is also remains relatively rare that historians from various Yugoslav successor states publish in the history journals of others of these states. It would certainly be a welcome development if, for example, more historians from Serbia published in Croatian journals and vice versa. And Serbia lacks historians' festivals of the type that are held in Croatia (Kliofest) and Bosnia and Herzegovina (History Fest).

70 Radina Vučetić, Koka-kola socijalizam: Amerikanizacija jugoslovenske popularne kulture šezdesetih godina XX veka (Belgrade: Službeni glasnik, 2012).

71 Radina Vučetić, Monopol na istinu: Partija, kultura i cenzura u Srbiji šezdesetih i sedamdesetih godina XX veka (Belgrade: Službeni glasnik, 2016).

72 Ivana Dobrivojević, Igor Duda, Sabina Mihelj and Ana Panić, They Never Had It Better? Modernization of Everyday Life in Socialist Yugoslavia (Belgrade: Muzej istorije Jugoslavije, 2014). See also Marina M. Simić, 'Muzealizacija socijalističkog nasleđa: preliminarna antropološka analiza Muzeja istorije Jugoslavije', Genero, 21 (2017), 117-35.

73 Vladimir Ivanović, Geburtstag pišeš normalno: Jugoslavenski gastarbajteri u Austriji i SR Nemačkoj (Belgrade: ISI, 2012). See also Predrag J. Marković, 'Gastabeiters as the Factor of Modernization in Serbia', Istorija 20. veka, 2 (2005), 145-63.

74 Miroslav Jovanović calculated that foreign authors accounted for only 9.6 per cent of the works published in the four most prominent Serbian history journals in the five years from 2003 to 2008. Miroslav Jovanović, 'Savremena srpska istoriografija: Karakteristike i trendovi', Istorija 20. veka, No. 1 (2010), 186. 
The comparatively difficult socioeconomic situation in which historians in Serbia - and in Southeastern Europe more generally - find themselves still restricts the extent to which many Serbian historians can engage internationally with their colleagues. Moreover, like colleagues in many countries in both Europe and North America, historians in Serbia have in recent years confronted research funding cuts and are increasingly subjected to publication metrics and the 'publish or perish' mentality.

Like historians in other countries, there is a visible and positive trend in Serbia regarding multidisciplinarity. Particularly among younger historians, there is a greater openness compared to earlier towards dialogues and collaboration with sociologists, anthropologists and scholars from other disciplines. Particularly noteworthy is the awareness and engagement of a younger generation of historians in Serbia with memory studies and the politics of memory. These historians aim to counter what Miroslav Jovanović criticised as being a stubbornly positivistic Serbian historiography 'removed from not just post-modernist controversy, but also from key methodological and theoretical dilemmas, considerations and polemics which characterise the main currents of the development of international historiography for more than the past half century. ${ }^{75}$ There is thus reason to hope that the chronic 'positivist archivitis' ( pozitivistički arhivitis) which Đorđe Stanković viewed as a widespread affliction among his colleagues is disappearing. ${ }^{76}$

Although there are many areas and topics where Serbian historiography has made handsome strides in the past two decades, there are also some major gaps. Regional and local histories remain relatively few in number. It would be great to see more written about the history of Vojvodina and Sandžak. The same of course applies to Kosovo, regardless of what stance is taken regarding its independence. ${ }^{77}$ Likewise, it would be good to see more - and more open-minded - research on ethnic and religious minorities in Serbia - Jews and Muslims, Albanians, Czechs, Germans, Hungarians, Roma, Ruthenians, Slovaks, Turks and others - and their interaction with the majority population.

In an interview in 1999 the late Andrej Mitrović noted that towards the end of Yugoslavia a tendency emerged in Serbia to portray Yugoslav history as a vain experiment which the Serbs had wasted their energy on during an entire century. ${ }^{78}$ But Mitrović also made another very essential and valid point for Serbian history. Pointing to the famous 'Fischer controversy' about the responsibility for the outbreak of the First World War, Mitrovic stated that Fischer had proved that a state, society or nation 'does not lose prestige by recognising the historical truth about itself.

As in so many other countries, the errors and atrocities committed in the name of 'our nation' have bedevilled historical scholarship in Serbia. Vuk Stefanović Karadžić, the father of the modern Serbian language, also dabbled in history and cooperated with none other than Leopold von Ranke. Interestingly, Karadžić was criticised for writing about how Ottoman Turks had been killed in Serbia in 1809. His critics believed that this dishonoured the Serb nation and by highlighting crimes which Serbs had committed. To this Karadžić responded that such criticism betrayed a false understanding of history. 'It is true that this is a disgrace for Serbs, but it was a disgrace to [commit the killings], and when it has already been done, it is not worth hiding in history' ${ }^{79}$ Two centuries

75 Miroslav Jovanović, 'Savremena srpska istoriografija: Karakteristike i trendovi', Istorija 20. veka, 1 (2010), 184. See also Radivoj Radić, 'Gde se nalazimo i kuda idemo', Godišnjak za društvenu istoriju, 3-4 (2014), 39-47; Miroslav Jovanović and Radivoj Radić, Kriza istorije: Srpska istoriografija i društveni izazovi kraja 20. i početka 21. veka (Belgrade, 2009).

76 Stanković defined this as 'the retelling of the content of documents of various provenances - without regard to their authenticity.' Đorđe Stanković, 'Dihotomija istorijske nauke u Srbiji', Tokovi istorije, 4 (2006), 239. Elsewhere Stanković wrote that 'the greatest ignoramus [neznalica] is not the one who does not know how to read, but the one who thinks that everything he has read is the truth'. Đorđe Stanković, 'Srpska medijalna kultura sećanja', Tokovi istorije, 3 (2006), 270.

77 It could of course be argued that the paucity of articles on Serbian regional history listed in this article reflects the choice of journals reviewed, but it would be an improvement if articles on regional history were not confined to regional journals.

78 Interview with Andrej Mitrović, Vreme, 9 Jan. 1999. It is worth noting that Mitrović gave this interview at a time when the Milošević regime still clung to the name Federal Republic of Yugoslavia.

79 Vuk Stefanović Karadžić quoted in Vladimir Petrović, 'Prilog proučavanje konstituisanja savremene istorije', Istorija 20. veka, 1 (2010), 175. 
later, Olga Manojlović-Pintar reminds us and her colleagues that history should also be about investigating and ascertaining one's own responsibility or even guilt for historical errors and wrongs. ${ }^{80}$ History cannot just be about glorifying the nation state, and historians must resist those who 'fear a catharsis of the Serb nation'. ${ }^{81}$

Ultimately, the historical profession in Serbia will have to decide what the primary reason for historical scholarship is. Will the remnants of a nineteenth-century view, in which the purpose of historical scholarship is to promote the interests and accomplishments of the nation state and its leaders, prove resilient and dominant? Certainly, this seems likely in a country in which so many historians depend on the funding of a state that continues to adhere to a nationalist agenda. And the recent decreases of international and European funding risk increasing the isolation of historians in Serbia. Or will a more progressive view, in which historical scholarship prioritises social and political criticism and scepticism of grand national narratives, instead emerge triumphant? To be sure, these are discussions that inform many other historiographies - from the besieged progressive historians and other scholars in neighbouring Hungary to debates regarding the place of slavery and other historical wrongs in the historiography and school textbooks of the United States.

Finally, the inexorable passage of time means that younger historians in Serbia increasingly have no living memory of Yugoslavia or, soon, of the 1990s. As Olga Manojlović-Pintar mused already a decade ago, it is to be hoped that they will be liberated from the ideological shackles and gladiatorial arenas in which some of their older colleagues have laboured and fought. ${ }^{82}$ Like a number of other historians, Manojlović-Pintar thinks and hopes that the historians of the future will be better placed to write history - including the history of the traumatic collapse of Yugoslavia and the ensuing atrocious wars - sine ire et studio.

\footnotetext{
80 Olga Manojlović-Pintar, 'O revizijama, dijalozima i kulturi sećanja', Tokovi istorije, 1-2 (2009), 208.

81 Đorđe Stanković, 'Srpska medijalna kultura sećanja', Tokovi istorije, 3 (2006), 269.

82 Olga Manojlović-Pintar, 'O revizijama', 207.
}

Cite this article: Nielsen CA (2020). Serbian Historiography after 1991. Contemporary European History 29, 90-103. https:// doi.org/10.1017/S096077731900033X 